Volume 44 | Issue 3

2012

\title{
Financial Controls and Counter-Proliferation of Weapons of Mass Destruction
}

Nikos Passas

Follow this and additional works at: https://scholarlycommons.law.case.edu/jil

Part of the International Law Commons

\section{Recommended Citation}

Nikos Passas, Financial Controls and Counter-Proliferation of Weapons of Mass Destruction, 44 Case W. Res. J. Int'l L. 747 (2012) Available at: https://scholarlycommons.law.case.edu/jil/vol44/iss3/29

This Article is brought to you for free and open access by the Student Journals at Case Western Reserve University School of Law Scholarly Commons. It has been accepted for inclusion in Case Western Reserve Journal of International Law by an authorized administrator of Case Western Reserve University School of Law Scholarly Commons. 


\title{
FinANCIAL CONTROLS AND COUNTER-PROLIFERATION OF WEAPONS OF MASS DESTRUCTION
}

\author{
Nikos Passas*
}

This paper focuses on financial controls and vigilance against the proliferation of Weapons of Mass Destruction (WMD). It refers to the new Financial Action task Force (FATF) Recommendations on this subject and outlines relevant provisions of the U.N. Security Council Resolutions (UNSCRs) and the considerable challenges facing the international community in their implementation. While it suggests that there is a good deal of work underway towards consistent and effective implementation, it points to some concrete measures and areas where counter-proliferation finance efforts could focus, particularly in the area of commerce and trade.

I. INTRODUCTION

II. U.N. SECURITY COUNCIL RESOLUTIONS

AND PROLIFERATION FINANCE

III. IMPLEMENTATION CHALLENGES

IV. CONCLUSION.

\section{INTRODUCTION}

Neither the use of financial sanctions as a tool to apply pressure on governments nor controversies and diverse interpretations of their effects are new. An early example from classical Greece is the Megarian Decree, under which Athens introduced a trade embargo on Megara merchants during the Pericles era. ${ }^{1}$ Aristophanes, ${ }^{2}$ Thucydides $^{3}$ and others ${ }^{4}$ offered

* Nikos Passas is a Professor at Northeastern University. His law degree is from the University of Athens, his Master's from the University of Paris II, and his Ph.D. from the University of Edinburgh. He is a member of the Athens Bar. Passas is fluent in six languages and specializes in the study of corruption, terrorism, money laundering, illicit flows, informal fund transfers, white-collar crime, targeted sanctions, organized crime and international crimes. He has more than 140 publications in thirteen languages. Passas offers public and private sector training, serves as an expert witness and consults with law firms, financial institutions, international organizations and government agencies on all continents. He serves as the Editor-in-Chief of Crime, Law and Social Change: An International Journal, and as an associate editor in several others. He is a member of the Board of Directors of the International Society of Criminology.

1 Carl A. Alex, Updating Economic Operations in the Post Industrial Age (March 1998) (unpublished Master of Science in Defense Analysis thesis, Naval Postgraduate School), available at http://www.dtic.mil/cgi-bin/GetTRDoc?AD=ADA343821. 
very different views: some suggested that it was effective, while Thucydides regarded it as a pretext for the war that followed.

The U.N. first introduced sanctions in the 1920s, but it employed them seldom in the years that followed. It was the 1990s that witnessed a significant growth in the use of such coercive measures. ${ }^{5}$ Aimed at global security threats in ways that could be effective but less radical than the use of force, ${ }^{6}$ their scope has widened, ranging from aggression and conflict to international terrorism and proliferation of weapons of mass destruction (WMD). ${ }^{7}$ Multilateral sanctions have been considered and applied due to proliferation concerns in several countries, ${ }^{8}$ but the most recent ones focus on non-state actors, the Islamic Republic of Iran, and the Democratic People's Republic of Korea (DPRK). ${ }^{9}$ Originally, counter-proliferation measures revolved chiefly around export controls, but these are now supplemented by financial control requirements for both governmental and private sector actors.

At the same time, "follow-the-money" approaches to crime control have been applied at both the national and international levels. ${ }^{10}$ Financial

2 Aristophanes, The Acharnians (S. Douglas Olson ed., 2002).

3 ThuCydides, History of THE PELOPONNESIAN WAR (Richard Crawley trans., 1903).

4 Jona Lendering, Megarian Decree, LIVIUS.ORG, http://www.livius.org/mea-mem /megara/decree.html (last updated Mar. 31, 2006); James McDonald, Supplementing Thycydideds' Account of the Megarian Decree, 2 EleCtRONIC ANTIQUITY, no. 3 1994, http://scholar. lib.vt.edu/ejournals/ElAnt/V2N3/mcdonald.html.

5 Enrico CARisch \& LoRAine Rickard-Martin, Global Threats and the Role of United Nations SAnCtions 2 (2011); see also GeORge A. Lopez \& DAvid CoRTright, The SANCTIONS DeCADE: AsSESSING UN STRATEGIES IN THE 1990s (2000).

6 See Gary Clyde Hufbauer, Economic Sanctions Reconsidered (3d ed. 2007); Peter Wallensteen \& Carina Staibano, International Sanctions: Between Words AND WARS IN THE GLOBAL SYSTEM (2005).

7 CARISCH \& RICKARD-MARTIN, supra note 5, at 3.

8 See Bernard Sitt et AL., SAnctions and Weapons of Mass Destruction in INTERNATIONAL RELATIONS 28 (2010) (noting that suspected WMD-producing states such as the Islamic Republic of Iran, Syria and the Democratic People's Republic of Korea are among the states targeted by WMD-related sanctions).

9 Nikos Passas, Ian Anthony, Genevieve Deanaz \& Janet Walker, Prevention of CBRN Illicit Trafficking and Deceptive Financial Practices: Report to the COMMISSION OF THE EUROPEAN UNION (2010).

10 This has been marked by differing degrees of success and heated debates among observers, such as JeFF Breinholt, TAXing Terrorism From Al CAPONE to Al QAidA: Fighting Violence Through Financial Regulation 1 (2005) (discussing the importance of follow the money methods as counterterrorism strategy); Nikos Passas, Terrorism Financing Mechanisms and Policy Dilemmas, in Terrorism FinANCING AND STATE ResPonses: A Comparative Perspective 21-38 (Jeanne K. Giraldo \& Harold A. Trinkunas eds., 2007) (arguing for a better balance of the costs and benefits of certain "follow the money" strategies); Peter Reuter \& Edwin M. Truman, Chasing Dirty Money 73 (2004) (suggesting that technological developments promote follow the money methods); Michael Levi \& Peter 
controls have been increasingly employed to address serious crime and security problems ranging from organized criminal group activities to corruption and the support of terrorism. These can be used for investigative and intelligence-gathering objectives - they assist in identifying co-conspirators, facilitators, and supporters-as well as for deterrence, disruption, punishment and confiscation purposes. The most recent addition to the list of unlawful practices targeted with this approach is the financing of WMD proliferation. In February 2012, the Financial Action Task Force (FATF), a body setting international standards on money laundering and terrorism finance, revised its Recommendations and incorporated the issue of proliferation finance. ${ }^{11}$ New Recommendation 7 is entitled "Targeted financial sanctions related to proliferation" and states that:

Countries should implement targeted financial sanctions to comply with United Nations Security Council resolutions relating to the prevention, suppression and disruption of proliferation of weapons of mass destruction and its financing. These resolutions require countries to freeze without delay the funds or other assets of, and to ensure that no funds and other assets are made available, directly or indirectly, to or for the benefit of, any person or entity designated by, or under the authority of, the United Nations Security Council under Chapter VII of the Charter of the United Nations. ${ }^{12}$

There is no legal and universally adopted definition of "proliferation finance." However, the FATF's working definition can be used for our purposes here:

Proliferation finance refers to the act of providing funds or financial services which are used, in whole or in part, for the manufacture, acquisition, possession, development, export, trans-shipment, brokering, transport, transfer, stockpiling or use of nuclear, chemical or biological weapons and their means of delivery and related materials (including both technologies and dual use goods used for non-legitimate purposes), in

Reuter, Money Laundering, 34 CRIME \& JUST. 289, 294 (2006) ("[T]he [anti-money laundering] regime does facilitate investigation and prosecution of some criminal participants who would otherwise evade justice, but fewer than expected and hoped for by advocates of 'follow the money' methods."); R.T. NAYlor, SATANiC PuRSES: Money, Myth, and MISINFORMATION IN THE WAR ON TERROR (criticizing measures imposed by the Patriot Act to facilitate follow the money strategies) (2008), and J.C. SHARMAn, THE MonEy LAUNDRY: REgulating CRiminal FinANCE IN THE GlobAl ECONOMY 71 (2011) (arguing that the ability to obscure transactions defeats follow the money efforts).

11 See Financial Action TASk Force [FATF], International Standards on Combating Money Laundering and the Financing of Terrorism and Proliferation: THE FATF RECOMMENDATIONS 47 (2012) (noting the new focus on proliferation financing in these Recommendations).

12 Id. at 13. 
contravention of national laws or, where applicable, international obligations. $^{13}$

This paper focuses on proliferation finance, outlines relevant provisions of the U.N. Security Council Resolutions (UNSCRs) and the challenges facing the international community in their implementation. While it suggests that there is a good deal of work towards consistent and effective implementation, it points to some concrete measures and areas where counter-proliferation finance efforts could focus. ${ }^{14}$

\section{U.N. SECURITY COUNCIL RESOLUTIONS AND PROLIFERATION FINANCE}

Chapter VII of the U.N. Charter provides that when the Security Council establishes a threat or breach of the peace or acts of aggression, it has the power to introduce measures ranging from "provisional measures" to the use of force. ${ }^{15}$ Article 41 lays down the legal basis on which sanctions can be applied:

The Security Council may decide what measures not involving the use of armed force are to be employed to give effect to its decisions, and it may call upon the Members of the United Nations to apply such measures. These may include complete or partial interruption of economic relations and of rail, sea, air, postal, telegraphic, radio, and other means of communication, and the severance of diplomatic relations. ${ }^{16}$

The obligations stemming from Resolutions issued under Chapter VII of the U.N. Charter are generally mandatory. Yet, room for interpretation exists in the language of some provisions. For instance, when the Resolutions state that Security Council "decides" or that Member States "shall" do something, there is no debate about their mandatory nature. However, when Member States are "called upon" to take certain measures,

13 FatF, Combating Proliferation Financing: A Status Report on Policy DEVElopMent AND Consultation (2010).

14 The paper draws largely on work I conducted while I was privileged to be part of a study team that produced a report for the Commission of the European Union, titled Prevention of CBRN Illicit Trafficking and Deceptive Financial Practices. Passas ET AL., supra note 9.

15 U.N. Charter arts. 39-42.

16 U.N. Charter art. 41.

The Security Council may decide what measures not involving the use of armed force are to be employed to give effect to its decisions, and it may call upon the Members of the United Nations to apply such measures. These may include complete or partial interruption of economic relations and of rail, sea, air, postal, telegraphic, radio, and other means of communication, and the severance of diplomatic relations.

Id. 
some argue that these provisions are not mandatory, while others believe that they are mandatory nonetheless. Such diverse interpretations obviously affect different countries' implementation and practices.

The international community has reached a broad consensus on the need to prevent WMD proliferation, but the use of financial controls to this effect is novel to both government agencies and the private sector. How exactly the new counter-proliferation tools can be integrated with or supplement more traditional controls is not entirely clear-even in countries strongly supportive of the new measures.

It is important to clarify what sort of measures are provided for by the various UNSCRs. The UNSCRs most relevant to a review of financial vigilance measures are:

- $1540,1673,1810,1887,1977$ on non-state actor proliferation;

- $1695,1718,1874$ on DPRK; and

- $1696,1737,1747,1803$, and 1929 on Iran.

These Resolutions establish Committees and occasionally Expert Groups in order to support and monitor their implementation. Their measures cover not only export- and border-control issues, but also:

- financial controls and vigilance;

- activity-based financial prohibitions;

- specific vigilance measures and actions on designated banks;

- freezing of assets;

- international cooperation and information sharing; and

- financial and technical assistance.

Resolution 1540 requires that States refrain from supporting by any means non-State actors from developing, acquiring, manufacturing, possessing, transporting, transferring or using nuclear, chemical or biological weapons and their delivery systems. ${ }^{17}$ The Resolution obliges States to establish domestic controls to prevent the proliferation of nuclear, chemical and biological weapons, and their means of delivery, including by establishing appropriate controls over related materials. ${ }^{18}$

It also mandates that States:

[A]dopt and enforce appropriate effective laws which prohibit any non-State actor to manufacture, acquire, possess, develop, transport, transfer or use nuclear, chemical or biological weapons and their means of delivery, in particular for terrorist purposes, as well as attempts to engage

17 S.C. Res. 1540, đ 1, U.N. Doc. S/RES/1540 (Apr. 28, 2004).

18 Id. $\mathbb{1} 3$. 
in any of the foregoing activities, participate in them as an accomplice, assist or finance them. ${ }^{19}$

Subsequently, the Security Council stressed the need for work under this and successor Resolutions to be coordinated with that of Committees operating under counter-terrorism Resolutions. Thus, UNSCR 1810 urged the enhanced cooperation "between the 1540 Committee, the Security Council Committee established pursuant to resolution 1267 (1999), concerning Al-Qaida and the Taliban, and the Security Council Committee established pursuant to resolution 1373 (2001) . .."20

With respect to Iran, UNSCR 1737 (2006) and subsequent Resolutions, the Security Council has adopted measures that include:

- An embargo on providing to Iran proliferation-sensitive nuclear and ballistic missile-related items listed in the main text or in annexes; ${ }^{21}$

- A ban on the procurement of any arms and related materiel from Iran and a ban on the supply of seven categories of conventional weapons and related materiel to Iran; ${ }^{22}$

- A travel ban and an assets freeze on specific persons and entities listed in annexes. This assets freeze also applies to any individuals or entities acting on behalf of, or at the direction of, the designated persons and entities, and to entities owned or controlled by them. ${ }^{23}$

The UNSCR financial measures regarding Iran are more specific than those relative to non-state actors. Some are broad-based and preventive in nature, but they contain specific and targeted sanctions as well. They also refer to obligations of both governments and financial institutions.

UNSCR 1737 contains several financial measures. Among other things, it requires that all States:

$[S]$ hall . . . take the necessary measures to prevent the provision to Iran of any technical assistance or training, financial assistance, investment, brokering or other services, and the transfer of financial resources or services, related to the supply, sale, transfer, manufacture or use of the prohibited items, materials, equipment, goods and technology specified [in paragraphs 3 and 4$]^{24}$

It further mandates that all States:

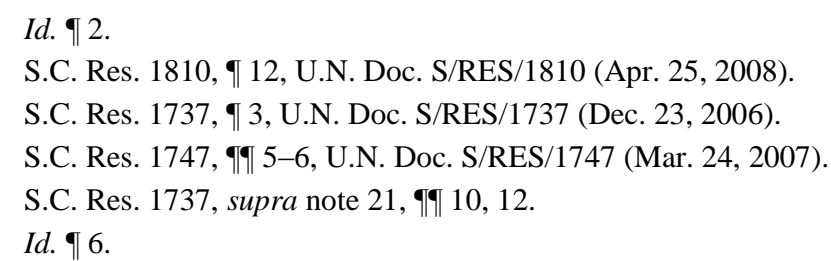


[S] hall freeze the funds, other financial assets and economic resources which are on their territories at the date of adoption of this resolution or at any time thereafter, that are owned or controlled by the persons or entities designated in the Annex, as well as those of additional persons or entities designated by the Security Council or by the Committee as being engaged in, directly associated with or providing support for Iran's proliferation sensitive nuclear activities or the development of nuclear weapon delivery systems, or by persons or entities acting on their behalf or at their direction, or by entities owned or controlled by them, including through illicit means .... 25

UNSCR 1803 introduced provisions that applied the measures of Paragraph 12 of UNSCR 1737 to expanded lists of persons and entities and increasingly called for vigilance over all trade and finance-as well as financial institutions - to prevent any support to Iran's nuclear proliferation activities. ${ }^{26}$ It also focused on financial institutions and two specific Iranian banks by:

Call[ing] upon all States to exercise vigilance over the activities of financial institutions in their territories with all banks domiciled in Iran, in particular with Bank Melli and Bank Saderat, and their branches and subsidiaries abroad, in order to avoid such activities contributing to the proliferation sensitive nuclear activities, or to the development of nuclear weapon delivery systems, as referred to in resolution 1737 (2006). ${ }^{27}$

UNSCR 1929 expanded the measures and extended some to explicitly cover insurance and re-insurance..$^{28}$ Additional measures applied to financial institutions as UNSCR 1929 called upon States to:

[T]ake appropriate measures that prohibit financial institutions within their territories or under their jurisdiction from opening representative offices or subsidiaries or banking accounts in Iran if they have information that provides reasonable grounds to believe that such financial services could contribute to Iran's proliferation-sensitive nuclear activities or the development of nuclear weapon delivery systems. ${ }^{29}$

With respect to DPRK, UNSCRs 1695 (2006) and especially 1718 (2006) and 1874 (2009) introduced a regime intended to force DPRK to comply with demands related to its nuclear and ballistic missile programs. The measures in this regime include:

\footnotetext{
Id. II 12.

See S.C. Res. 1803, III 9-10, U.N. Doc. S/RES/1803 (Mar. 3, 2008).

Id. II 10.

See S.C. Res. 1929, đI 21, U.N. Doc. S/RES/1929 (June. 9, 2010).

Id. $\mathbb{I} 24$.
} 
- An embargo on the supply of nuclear, ballistic missiles and other weapons of mass destruction program-related items listed in UNSC documents; $;^{30}$

- A complete arms embargo with the exception of small arms and light weapons and their related materiel, which can be supplied using controlled channels and after prior notification to the Security Council ${ }^{31}$

- Individual targeted sanctions in the form of a travel ban and an assets freeze on designated persons and entities; ${ }^{32}$ and

- A ban on the export of luxury goods to the North Korea. ${ }^{33}$

UNSCR 1718 mandated a freeze of:

[F] unds, other financial assets and economic resources which are on their territories at the date of the adoption of this resolution or at any time thereafter, that are owned or controlled, directly or indirectly, by the persons or entities designated by the Committee or by the Security Council as being engaged in or providing support for, including through other illicit means, DPRK's nuclear-related, other weapons of mass destructionrelated and ballistic missile related programmes, or by persons or entities acting on their behalf or at their direction, and ensure that any funds, financial assets or economic resources are prevented from being made available by their nationals or by any persons or entities within their territories, to or for the benefit of such persons or entities. ${ }^{34}$

Extending further previous sanctions, UNSCR 1874 called upon Member States:

[T] o prevent the provision of financial services or the transfer to, through, or from their territory, or to or by their nationals or entities organized under their laws (including branches abroad), or persons or financial institutions in their territory, of any financial or other assets or resources that could contribute to the DPRK's nuclear-related, ballistic missilerelated, or other weapons of mass destruction-related programs or activities, including by freezing any financial or other assets or resources on their territories or that hereafter come within their territories, or that are subject to their jurisdiction or that hereafter become subject to their jurisdiction, that are associated with such programs or activities and

30 S.C. Res. 1718, II 8(a)(ii), U.N. Doc. S/RES/1718 (Oct. 14, 2006).

31 S.C. Res. 1874, II 10, U.N. Doc. S/RES/1874 (June 12, 2009).

32 S.C. Res. 1718 , supra note 30 , গाI 8 (d) \& (e).

33 See Security Council Imposes Sanctions on DPR Korea After its Claimed Nuclear Test, UN NEws CENTRE (Oct. 14, 2006), http://www.un.org/apps/news/story.asp?NewsID=20261 $\& \mathrm{Cr}=\mathrm{DPRK} \& \mathrm{Cr} 1$ ("Also prohibited from export to the DPRK are luxury goods.").

34 S.C. Res. 1718, supra note 30, II 8(d). 
applying enhanced monitoring to prevent all such transactions in accordance with their national authorities and legislation. ${ }^{35}$

UNSCR 1874 also called upon:

[A]ll Member States and international financial and credit institutions not to enter into new commitments for grants, financial assistance, or concessional loans to the DPRK, except for humanitarian and developmental purposes directly addressing the needs of the civilian population, or the promotion of denuclearization, and also calls upon States to exercise enhanced vigilance with a view to reducing current commitments. $^{36}$

In practical terms, implementing such measures may require new domestic legislation; the introduction of preventive measures and monitoring; enhanced enforcement capacity; and actions to be taken by privatesector entities, especially financial institutions.

Two categories of measures can be usefully distinguished in these provisions. One category includes targeted financial sanctions centered on actors of concern, while the other is based on activities that support proliferation efforts or programs.

Targeted financial sanctions generally "entail the use of financial instruments and institutions to apply coercive pressure on transgressing parties-government officials, elites who support them, members of nongovernmental entities - in an effort to change or restrict their behavior." 37 This type of measure can thus target specific persons or entities, their assets, and their transactions because of their involvement in proliferation activities. Occasionally, the names of targets are cited in the main text of Resolutions.$^{38}$ More often, however, the list of targeted actors is appended.

For example, UNSCR 1737 Paragraph 5's provisions on asset freezes cited earlier should be applied to any other persons or entities "engaged in, directly associated with or providing support for Iran's proliferation sensitive nuclear activities or the development of nuclear weapon delivery systems, or by persons or entities acting on their behalf or at their direction, or by entities owned or controlled by them, including through illicit means . . . ."39 It also required that all States "shall ensure that any funds, financial assets or economic resources are prevented from being

35 S.C. Res. 1874, supra note 31, II 18.

36 Id. 1019.

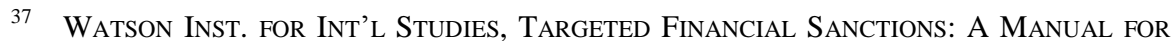
DESIGN AND IMPLEMENTATION, at ix (2001).

38 See S.C. Res. 1929, supra note 28, IIII 8, 10 (discussing measures to restrict the Islamic Republic of Iran Shipping Lines (IRISL), or those acting on their behalf or at their direction).

39 S.C. Res. 1737 , supra note $21, \mathbb{I} 12$. 
made available by their nationals or by any persons or entities within their territories, to or for the benefit of these persons and entities." 40 The provisions cited above regarding specific Iranian banks and entities of the Islamic Republic of Iran Shipping Lines also fall in this category. An example from the DPRK regime is provided by Paragraph 8(d) of UNSCR 1718 as cited above.

On the other hand, activity-based measures relate to specific actions and transactions, such as financing or insurance, linked to proliferation efforts. For example, UNSCR 1540 requires states to establish "appropriate laws and regulations to control export, transit, trans-shipment and re-export and controls on providing funds and services related to such export and trans-shipment such as financing . . . " A1 According to UNSCR 1540, financial controls should be available for application to any exports of controlled items, regardless of destination. ${ }^{42}$ How and when these legal instruments are applied is left to the discretion and best judgment of the national authorities in the exporting state concerned.

There are also provisions that require countries to apply activityrelated controls against particular countries, such as Iran and DPRK. An illustration of this type are the measures of Paragraph 6 of UNSCR 1737 regarding technical assistance or training, financial assistance, etc., related to the prohibited items specified in that resolution. ${ }^{43}$ More recently, UNSCR 1929 mandates that States "prevent the provision to Iran by their nationals or from or through their territories of technical training, financial resources or services, advice, other services or assistance related to the supply, sale, transfer, provision, manufacture, maintenance or use" of specified conventional arms and related materiel. ${ }^{44}$ In such cases, the Security Council targets financial, commercial and service flows connected to activities supportive of programs of concern in these countries while allowing other transactions with these countries that are not subject to restrictions.

The exhaustive listing of requirements and obligations of U.N. Member States is beyond the scope of this paper, but it is clear that they vary not only by type of measure, but also by the particular targets, the implementing national authorities, and the responsibilities of individuals and private sector entities.

\footnotetext{
${ }^{40} \quad I d$.

41 S.C. Res. 1540, supra note 17, I[ 3(d).

${ }^{42} I d$.

43 S.C. Res. 1737, supra note 21, II 6.

44 S.C. Res. 1929, supra note 28, II 8.
} 


\section{IMPLEMENTATION CHALLENGES}

A review of Member State reports to the various U.N. Security Council sanctions committees on what they have done to implement the Resolutions discussed here reveals a wide variety of approaches with respect to financial vigilance. Many States refer to their money laundering, terrorism or terrorism-finance laws as measures responsive to the UNSCRs. Other States simply notify national authorities of the UNSCRs' passage. A small number of governments have considered or introduced specific new measures and laws. France, for instance, has passed a law with three separate offenses against the finance of proliferation of nuclear, chemical, and biological weapons. ${ }^{45}$ On the other extreme, some countries have not even filed a required progress report to the relevant committees. ${ }^{46}$

This global asymmetry of national laws against proliferation finance is matched by the asymmetry in the existence, strength and application of national export controls. While there is no systematic and comprehensive review of these diverse laws and practices, it is crystal clear that there is plenty of room for improving the way the global community addresses proliferation threats.

The challenges are legion. We have already noted the lack of a universal definition of the term "proliferation finance" and the uncertainty about which obligations stemming from the different UNSCRs are mandatory, even when they are under Chapter VII of the U.N. Charter. This uncertainty is of course not coincidental, as it indicates the diverse interests, priorities, and objectives of the members of the Security Council. Consensus has not been reached even within the group of the five permanent members of the Security Council. The ambiguity of terms, such as "financial services," "other services," "Iranian-controlled bank," "reasonable grounds to believe," and "entity under control,"-which are neither defined nor operationalized-makes it unclear what concrete steps are required. ${ }^{47}$

45 See Loi 2011-266 du 14 mars 2011 relative à la lutte contre la prolifération des armes de destruction massive et de leurs vecteurs [Law 2011-266 of March 14, 2011 on the Fight Against the Proliferation of Weapons of Mass Destruction and their Delivery], Journal Officiel de la République Française [J.O.] [Official Gazette of France], Mar. 15, 2011, p. 4577, arts. 2, 5, 11, available at http://legifrance.gouv.fr/affichTexte.do?cidTexte=JORFTEXT 000023707202\&categorieLien=id.

46 See Cole J. Harvey, Two Steps Forward, One Step Back: Slow, but Steady Progress Implementing UNSCR 1540, NUCLEAR THREAT INITIATIVE (July 20, 2011), http://www.nti. org/analysis/articles/unscr-1540/ (noting that only 59 states met the deadline to submit national implementation reports six months following the passage of Resolution 1540).

47 The FATF has issued three helpful sets of non-binding guidance. See generally FATF, Guidance Regarding the Implementation of Financial Provisions of United Nations SeCurity Council Resolutions to Counter the Proliferation of Weapons of Mass Destruction, Annex (June 29, 2007), available at http://www.fatf-gafi.org/dataoecd/23/16 
A complicating factor for both government bodies and financial institutions is the existence of related sanction regimes and financial controls at the regional and national level, notably by the $\mathrm{EU}^{48}$ and the U.S. ${ }^{49}$ These controls go beyond the requirements of the Security Council, have extra-territorial implications, and have been the subject of frequent additions and amendments, reflecting geo-political developments and perceptions of proliferation risks.

Beyond legal uncertainties, other implementation difficulties range from lack of capacity and awareness, political will, commercial concerns, and lack of coordination to the neglect of guidance and outreach to the private sector. ${ }^{50}$ One particular issue worth dwelling upon is the issue of proliferators' increased sophistication in recent years and the connection between proliferators and other crime or security concerns.

Proliferating networks appear to be involving multiple production facilities, more countries, intermediaries, and trans-shipment points, all while compartmentalizing operations and occasionally breaking procurement down to parts and small amounts, which are difficult to detect or trace. As the FATF notes, "while proliferators previously attempted to buy or sell whole manufactured systems with the effective control systems, there is a growing trend to purchase or sell more elementary components. Proliferation networks continuously seek out and exploit weaknesses in the global export control system and international financial system."

Moreover, rising trade volumes coupled with technological advances have led to more complex trading patterns, rendering export controls more difficult to manage and maintain. In the area of WMD components, the same FATF report has noted the difficulty in dealing with "dual-use" goods with both commercial applications and applications for WMD. ${ }^{52}$ By masking WMD-related procurement activities as legitimate trade, proliferators tend to exploit global commerce by operating in and

139318680.pdf; FATF, ProlifERATION FinANCING REPORT (June 18, 2008), available at http://www.fatf-gafi.org/dataoecd/14/21/41146580.pdf; FATF, BEST PRACTICES PAPER: SHARING Among DOMEstic COMPETENT Authorities InFormation Related to the FinANCING OF PROLIFERATION (Feb. 2012), available at http://www.fatf-gafi.org/dataoecd/5/ 31/49848736.pdf (explaining the terms in more context).

48 Consolidated List of Persons, Groups, and Entities Subject to EU Financial Sanctions, EU: EXTERNAL ACTION, http://eeas.europa.eu/cfsp/sanctions/consol-list_en.htm (last updated May 4, 2012).

49 See Sections Programs and County Information, U.S. DeP'T Treasury, http://www. treasury.gov/resource-center/sanctions/Programs/Pages/Programs.aspx (last visited Apr. 14, 2012) (listing the OFAC sanctions programs).

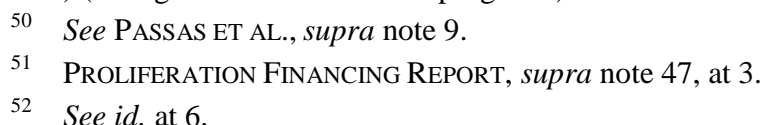


through countries with high volumes of cross-border trade or free-trade zones, where their illicit shipments may escape close scrutiny.

Even though we lack perfect knowledge of the social organization of proliferation networks and their interface with organized criminal groups or public officials, there is information to suggest that they resort to nominees, front companies, informal channels and methods employed in the commission of other offences (e.g., Customs, commercial and subsidy frauds, tax evasion, corruption, trade-based money laundering, etc.).

The open-source literature has not yet discussed proliferation finance in detail. Indeed, this topic may be neglected even within governments and international organizations. Typically, agencies and countries do not share such information, which has hampered some study efforts. Yet we do know that financial institutions' suspicious activity reports have triggered some such cases. ${ }^{53} \mathrm{We}$ also know that financial transaction information has served well intelligence gathering, investigative, and prosecutorial efforts in various countries. ${ }^{54}$ Quite often, investigations and prosecutions were initiated under laws targeting money laundering, fraud or corruption.

As proliferators seek to circumvent sanctions and other measures, their open-account, nominee, compartmentalized and deceptive practices become harder for financial institutions and government agencies to detect. Additionally, as efforts focus on the financial sector, proliferators may make more use of informal financial and trade networks, which are misunderstood in many parts of the world and difficult to monitor. ${ }^{55}$ Quite extensive informal financial, remittance, and trade networks operate in key areassuch as South and Southeast Asia, the Middle East, the Caribbean and South America-have been connecting jurisdictions of concern and neighboring countries.

Whether or not sanction regimes and financial controls are successful in producing the intended outcomes, they generate effects and raise the cost of proliferation efforts. Past experiences show that among the unintended consequences of sanctions is a certain criminalization of both

53 See PASSAS ET AL., supra note 9.

54 See Catherine Collins \& Douglas Frantz, Fallout: The True Story of the CIA's SECRET WAR ON NuClEAR TRAFFICKING 126 (2011); Gordon CORERA SHOPPING FOR Bombs: Nuclear Proliferation, Global Insecurity, and the Rise and Fall of the A.Q. KHAN Network 166 (2006); see also CATHERINe Collins \& Douglas Frantz, The Nuclear Jihadist: The True Story of the Man who Sold the World's Most Dangerous Secrets... And How We Could Have Stopped Him (2007).

55 See Nikos Passas, Informal Value Transfer Systems, Terrorism and Money Laundering 16, 96-97, 100 (2003) (report to the National Institute of Justice (NIJ) and Financial Crimes Action Network (FINCEN)), available at https://www.ncjrs.gov/pdffiles1/nij/grants/208301. pdf (discussing that informal systems and trade facilitated transfer need to be monitored and should be kept in line with FATF recommendations). 
public- and private-sector actors in target and neighboring countries through which illegal flows are routed. ${ }^{56}$ Criminal infrastructures, methods, networks, and associations brought about by the demand for prohibited goods and services survive sanctions regimes and pose a longer-term governance threats.

Confronting such threats necessitates the consideration of five key points emerging from research into financial crime and specifically relevant to money laundering, terrorism finance and corruption that are common to proliferation finance. These five key points consist of the need for: (1) evidence-based policy making; (2) practices that transcend the current fragmentation of controls that focus on particular offenses; and (3) a strategic approach that (4) includes outreach and partnership with the private sector as well as the academic community and (5) ensures that data on the global flows of information, commerce and finance are collected, rendered traceable, analyzed, and matched in order to identify irregular and suspicious activities, to piece together the bigger picture of serious financial misconduct and networks, illuminating the economic activity currently taking place in the shadows.

Briefly, here are the main issues from each point:

1) Too much crime control and policy has been based on assumptions, suspicions and theories rather than carefully collected and strong evidence about the problem at hand.$^{57}$ As with terrorism finance, we must gather the facts and understand well proliferation activities and networks, their division of labor and methods of operation.

2) Unusual activities that raise suspicion and initial investigations will often not flag a particular underlying offense. The details about the motives and aims of the offenders emerge gradually as inquiries progress. The same applies to sanctions violations and proliferation efforts. Firewalls and strict division of labor that discourage or prevent sharing of information among different control agencies undermine the fight against serious crime and security threats.

3) Given the plethora of challenges facing the implementation of a counter-proliferation finance regime, success and effectiveness is a longterm goal that can be reached progressively and systematically. The project is complex, sensitive and in need of consensual knowledge and a thoughtful sequencing of immediate steps and medium term objectives, while anticipating and minimizing as much as possible adverse consequences.

56 Gary Clyde HufBauer, Economic SAnctions ReCONSIDERED 44-48 (2007).

57 Cynthia Lum \& Leslie W. Kennedy, Evidence-Based Counterterrorism Policy, in Springer Series on Evidence-B ASEd Crime Policy 3, 3-8 (Cynthia Lum \& Leslie W. Kennedy eds., 2012) (stating that crime policy ought to be based on scientific studies and on valid empirical data analysis). 
4) The best ideas and sustainable solutions can only be achieved through multi-stakeholder interactions and collaborations. Guidance from government agencies help private sector entities and compliance officers better identify irregular and problematic accounts, clients or transactions and report them to appropriate authorities, such as the Financial Intelligence Units. Better quality and targeted reporting assists investigations and intelligence analysis as it often provides information otherwise unavailable to government agencies. Risk-based approaches can only be done effectively, when the risks are properly identified, understood and prioritized. Academic and research institutions can assist in this effort by creating new technologies enhancing controls and by engaging in systematic, comprehensive and critical analysis of data and evidence contributing to improved rule-making, policy construction, planning, facilitating multi-stakeholder interactions and training.

5) Research has shown that significant numbers of abuses, irregular and suspicious commercial activities involving billions of U.S. dollars in value every year go undetected due to lack of transparency, traceability and analysis of these transactions on their own and in comparison with the financial data that relate to them. This is a major vulnerability undermining all financial controls the global community has been implementing over the years. ${ }^{58}$ As Passas and Flynn point out:

The fundamental challenge that remains to be faced head on is how the global flows of information/intelligence, finance, trade and services can be made traceable and analyzed at the same time, in the same place. This is the only way one can piece together the puzzle so as to reveal a comprehensive picture of how criminal global networks are able to move and benefit from billions of dollars of profits generated from illicit activities. ${ }^{59}$

\section{CONCLUSION}

Proliferation of WMD is a top priority security concern, and financial controls are a recent and necessary addition to the international community's toolkit. The policy implications of the challenges discussed in this paper can be a rather lengthy report per se. The urgent needs include clearer UNSCR mandates, guidance to implementers, and analysis of the relationship correspondence between them and regional or national sanction

58 See Nikos Passas, Setting Global CFT Standards: A Critique and Suggestions, 9 J. Money Laundering ConTrol 281(2006); Nikos Passas, Terrorist Finance, Informal Markets, Trade and Regulation: Challenges of Evidence in International Efforts, in SPRINGER SERIES ON EVIDENCE-BASEd CRIME POLICY 255 (Cynthia Lum \& Leslie W. Kennedy eds., 2011).

59 See Nikos Passas \& Stephen Flynn, Overcoming the Mexican Trade Facilitated Money Laundering Challenge (this paper is to be presented at the Southwest Border Anti-Money Laundering Alliance, June 13-14, 2012, in Scottsdale, Arizona) (on file with author). 
regimes. One helpful precedent to consider is the approach taken by the U.N. Office on Drugs and Crime, which published legislative guides for the implementation of recent and complex international conventions against transnational organized crime and against corruption. ${ }^{60}$ The task there was to explain what is necessary for effective implementation without interpreting the conventions. This took painstaking effort to negotiate and reach consensus on their language and requirements, while giving examples of implementation in different legal traditions. Given the sensitivity around proliferation finance issues and controls, an equivalent initiative on UNSCRs would be welcome by Member States and the private sector. The FATF's forthcoming methodology for the assessment of compliance with its new 40 Recommendations could possibly pave the ground for more harmonized approaches too.

The study of proliferation cases and the mapping of proliferation networks, their operations, and their nexus with conventional, informal, and illegal actors is a necessary step towards the construction of an evidencebased strategy in cooperation with the private sector as well as academia.

An important issue raised above is the need to rethink crime control beyond specific offenses and defenses against them. The same methods, routes, and infrastructures can be used for a whole range of crimes: offenders most often do not specialize in one crime. Crime controls, especially for serious security threats, must be better organized and coordinated. Financial controls are sometimes resisted as an unnecessary distraction from border and expert controls. Increasingly, they are seen as very useful supplements to all kinds of serious crime. Ideally, they do not just supplement other controls but they all get integrated, which is arguably the only way in which national, regional, and international efforts will be truly effective.

Awareness-raising, training- and capacity-building, gaming exercises, technical assistance to countries and international bodies, further elaborations and operationalization of the risk-based approach to tackling financial crimes, expert panels, and committees are all important actions and recommendations. Nevertheless, the critical objective in this global effort is to appreciate that counter-proliferation and serious crime control is one and the same enterprise. If we adequately control proliferation, we will control financial and other crime. If we effectively control serious crime in general, we will also detect, capture, and disrupt proliferation attempts. In

60 U.N. OfFice on Drugs AND CRime Division for Treaty AfFAiRs, Legislative Guides FOR THE IMPLEMENTATION OF THE UNITED NATIONS CONVENTION AGAinst TRANSNATIONAL Organized Crime And the Protocols Thereto, U.N. Sales No. E.0000000 (2004); U.N. OfFice on DRugs and CRime Division for Treaty AfFairs, Legislative Guides FOR the Implementation of the United Nations Convention Against CoRruption, U.N. Sales No. E.06.V.16 (2006). 
order to accomplish this, we must address the challenge of the three global flows: commercial, financial and informational. Research and policy energies and brainpower ought to be invested in the quite-feasible ${ }^{61}$ task of collecting and analyzing the data; rendering them traceable; matching them; producing investigative leads; building the "big picture" of crime and security threats; and leading to pragmatic, sustainable strategies.

61 An initiative in exactly this direction is currently underway at Northeastern University as a collaboration between the Kostas Institute for Research in Homeland Security, the School of Criminology and Criminal Justice and the College of Computer Sciences. 